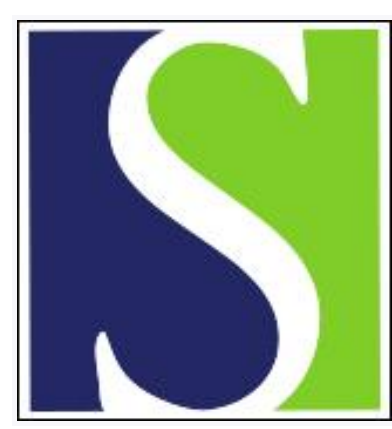

Scand J Work Environ Health 1997;23(5):385-391

https://doi.org/10.5271/sjweh.236

Issue date: Oct 1997

Sensitization to industrial enzymes in enzyme research and production

by Vanhanen M, Tuomi T, Nordman H, Tupasela O, Holmberg PC, Miettinen M, Mutanen P, Leisola M

Key terms: allergy; alpha-amylase; biotechnology; cellulase; exposure response; occupational asthma; phytase; rhinitis

This article in PubMed: www.ncbi.nlm.nih.gov/pubmed/9403470

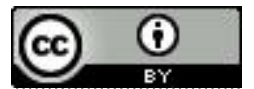




\title{
Sensitization to industrial enzymes in enzyme research and production
}

\author{
by Markku Vanhanen, MD, ${ }^{1}$ Timo Tuomi, PhD, ${ }^{1}$ Henrik Nordman MD, ${ }^{1}$ Outi Tupasela, MSc, ${ }^{1}$ \\ Peter C Holmberg, MD, ${ }^{2}$ Marja Miettinen, MD, ${ }^{3}$ Pertti Mutanen, MSc, ${ }^{1}$ Matti Leisola, DTech ${ }^{2}$
}

\begin{abstract}
Vanhanen M, Tuomi T, Nordman H, Tupasela 0, Holmberg PC, Miettinen M, Mutanen P, Leisola M. Sensitization to industrial enzymes in enzyme research and production. Scand J Work Environ Health 1997;23(5):385—91.

Objectives This study investigated sensitization to industrial enzymes in Finnish enzyme production and in Finnish laboratories.

Methods A cross-sectional study was conducted in 2 plants producing industrial enzymes and in their product development and research laboratories. Sensitization to enzymes and environmental allergens was examined by skin prick tests and specific immunoglobulin $\mathrm{E}$ determinations (radioallergosorbent test). The employees were interviewed for work-related respiratory symptoms. Altogether 173 employees were examined.

Results The skin prick test showed 21 employees (12\%) to be sensitized to one or more enzymes. Sixteen positive persons also had specific immunoglobulin E. Atopy was distinctly associated with enzyme sensitization. An exposure-response relationship was found for enzyme sensitization and for respiratory symptoms during work. For sensitization, the exposure-response linear trend was statistically significant. It weakened but remained statistically significant after stratification for atopy. For symptoms, likewise, the exposure-response linear trend was statistically significant, and the statistical significance remained after stratification for atopy. Conclusion The study confirmed that industrial enzymes are potent sensitizers. The handling of dry enzymes in laboratory work may cause sensitization. Sensitization may even follow minute degrees of exposure, such as among office personnel. Atopics are more susceptible to sensitization than nonatopics. Nonatopics are also clearly at risk; the demonstrated exposure-response relationship emphasizes the need for and advantages of proper exposure control.
\end{abstract}

Key terms allergy, alpha-amylase, biotechnology, cellulase, exposure response, occupational asthma, phytase, rhinitis.

Allergies to powdered microbial enzymes appeared in the late 1960 s in the detergent industry $(1,2)$, where bacterial (Bacillus subtilis) proteases, subtilisins, were the causative agents. With improvements in industrial hygiene the problem abated (2). Later on, with the increased production and use of new enzymes since the $1980 \mathrm{~s}(3,4)$, allergies have emerged in other industries, too, especially in bakeries to fungal (Aspergillus oryzae, Aspergillus niger) alpha-amylase (4-7). Some reports of allergies in laboratories and pharmaceutical companies have also been published. The studies have shown allergies to, for example, alpha-amylase and cellulase $(8,9)$.

The research and production of, especially, cellulases and hemicellulases increased quickly in Finland in the late 1980s (10). Soon allergies were observed, as indicated by 4 cases reported by Tarvainen et al (11). As in other countries, the use of enzymes increased in Finnish bakeries, as did sensitization to enzymes (12).
The aim of our study was to investigate the prevalence of enzyme sensitization in a biotechnical research laboratory and in another plant where product development and the production of industrial enzymes took place. Technical and hygienic improvements were made at both workplaces. Follow-up tests were carried out to determine whether the intervention had been sufficient to prevent new cases. The studies were performed in $1991-1993$

\section{Subjects and methods}

\section{Subjects}

Employees $(\mathrm{N}=94)$ in a biotechnical research laboratory (plant $\mathrm{A})$ and employees $(\mathrm{N}=79)$ in another biotechnical plant (plant B), consisting of a laboratory for

1 Finnish Institute of Occupational Health, Helsinki, Finland.

2 Cultor Ltd, Technology Center, Kantvik, Finland.

3 Alko Ltd, Helsinki, Finland.

Reprint requests to: Dr Markku Vanhanen, Finnish Institute of Occupational Health, Topeliuksenkatu 41 a A, FIN-00250 Helsinki, Finland. 
process control and product development, an enzyme production unit and a baker's yeast production unit, were investigated. Participation was voluntary, the participation rate being $90 \%$. In plant $A$, the tested employees consisted of 79 persons engaged in enzyme research in the laboratory and 15 doing office work. Plant B consisted of 27 researchers and laboratory workers, 25 enzyme process workers, 22 workers from baker's yeast production, and 5 office workers. Table 1 summarizes data on the workers' ages, smoking habits, and durations of employment.

\section{The plants studied}

The laboratory in plant $\mathrm{A}$ was a biotechnical research unit where several enzymes have been investigated for over 10 years. These enzymes included alpha-amylases, glucoamylase, proteases, glucose oxidase, cellulases, and hemicellulases. Especially the research of cellulases and xylanases of Trichoderma reesei origin increased markedly in the mid-1980s. Part of the enzymes were dry dusty preparations, particularly the cellulases. Dry enzymes were generally handled in laboratory exhaust hoods, but often also outside them. Most of the employees had worked sometimes also in fermentation rooms, where enzyme exposure was probable. A work phase with marked exposure was the preparation of enzyme mixtures in an open mill for research purposes. Some of the employees started to experience respiratory symptoms at work in the late $1980 \mathrm{~s}$. Two cases of occupational asthma due to cellulases were diagnosed, as described by Tarvainen et al (11). Moreover, 3 additional workers were diagnosed as having occupational asthma due to enzymes. After the appearance of this cluster of diseases, the hygienic conditions of the worksite were improved. The handling of dusty enzyme preparations was removed to specific rooms with separate ventilation arrangements. In addition protective clothing and respiratory masks were furnished for dusty operations associated with exposure to dry enzymes. Our study was performed 1.5 years later.
In plant B enzymes had been produced and investigated since 1985. The main products were cellulase and xylanase of Trichoderma reesei origin. Phytase and alpha-amylases were also produced, but on a smaller scale. In the production processes, the workers also handled dry enzymes. Enzyme drying was performed only occasionally in the plant itself. In the laboratory, both liquid and powdered enzyme preparations were handled routinely, usually without respiratory protection. Another sector of the plant produced baker's yeast in a separate building. After 2 cases of occupational asthma due to cellulase were diagnosed, and the experiences from plant A were recognized, a study was planned to assess the prevalence of enzyme sensitization. As in plant A, hygienic improvements were then made in the plant and laboratory.

\section{Exposure to enzymes}

The workers were divided into 3 exposure groups according to the frequency of work phases in which concentrations of enzymes were assessed as significantly higher than in the general workroom air. The minimum time of work in the tasks in question was required to be 6 months for groups 1 and 2 . The evaluation of the work areas and the worktasks was done by personal interview in connection with the skin prick tests and by workplace visits by an industrial hygienist (TT) and a specialist in occupational medicine (MV).

The exposure categories were defined as "often exposed" (group 1), comprised of workers who had commonly handled both the dry and liquid form of enzymes or worked often in rooms where dry preparations were handled by others; "occasionally exposed" (group 2), including workers who had handled the liquid form of enzymes and only occasionally worked in rooms where dry preparations were handled by others; and "rarely or not exposed" (group 3), made up of workers who did not handle enzymes themselves but may have worked in laboratories where the liquid form of enzymes was handled. Office personnel was included in the last group.

Table 1. Gender, age smoking, and duration of employment of employees by plant and exposure group.

\begin{tabular}{|c|c|c|c|c|c|c|c|c|c|}
\hline & \multicolumn{2}{|c|}{ Gender } & \multicolumn{4}{|c|}{ Age (years) } & \multicolumn{2}{|c|}{ Smokinga } & \multirow{3}{*}{$\begin{array}{l}\text { Mean } \\
\text { duration of } \\
\text { employment } \\
\text { (years) }\end{array}$} \\
\hline & \multirow[t]{2}{*}{ Men } & \multirow[t]{2}{*}{ Women } & \multicolumn{2}{|c|}{ Men } & \multicolumn{2}{|c|}{ Women } & \multirow[t]{2}{*}{$N$} & \multirow[t]{2}{*}{$\%$} & \\
\hline & & & Mean & Range & Mean & Range & & & \\
\hline \multicolumn{10}{|l|}{ Plant $A(N=94)$} \\
\hline $\begin{array}{l}\text { Group } 1(N=29) \\
\text { Group } 2(N=33) \\
\text { Group } 3(N=32)\end{array}$ & $\begin{array}{r}16 \\
11 \\
9\end{array}$ & $\begin{array}{l}13 \\
22 \\
23\end{array}$ & $\begin{array}{l}40.6 \\
39.2 \\
35.3\end{array}$ & $\begin{array}{l}26-58 \\
30-51 \\
26-43\end{array}$ & $\begin{array}{l}36.4 \\
40.4 \\
39.4\end{array}$ & $\begin{array}{l}28-44 \\
27-63 \\
26-56\end{array}$ & $\begin{array}{l}13 \\
10 \\
10\end{array}$ & $\begin{array}{l}39.4 \\
30.3 \\
30.3\end{array}$ & $\begin{array}{l}5.9 \\
5.5 \\
3.9\end{array}$ \\
\hline \multicolumn{10}{|l|}{ Plant $B(N=79)$} \\
\hline $\begin{array}{l}\text { Group } 1(N=34) \\
\text { Group } 2(N=18) \\
\text { Group } 3(N=27)\end{array}$ & $\begin{array}{r}19 \\
7 \\
14\end{array}$ & $\begin{array}{l}15 \\
11 \\
13\end{array}$ & $\begin{array}{l}40.4 \\
44.7 \\
48.6\end{array}$ & $\begin{array}{l}27-49 \\
35-53 \\
32-58\end{array}$ & $\begin{array}{l}36.7 \\
39.5 \\
44.6\end{array}$ & $\begin{array}{l}23-54 \\
31-54 \\
23-62\end{array}$ & $\begin{array}{r}14 \\
2 \\
8\end{array}$ & $\begin{array}{r}58.3 \\
8.3 \\
29.6\end{array}$ & $\begin{array}{l}4.7 \\
5.0 \\
5.4\end{array}$ \\
\hline
\end{tabular}

a Smokers $=$ current + ex-smokers. 
Their enzyme exposure was estimated as possible because their workrooms were often situated in the same building as the laboratories. The group also comprised the employees in baker's yeast production in plant B. They worked in a separate building and did not normally visit enzyme production facilities. It was possible to meet the personnel, for example, in the canteen during lunch.

\section{Questionnaire}

The employees answered a questionnaire on work history, history of atopy, smoking habits, and work-related symptoms. The questionnaire was a modification of sets of questionnaires that have been used in several epidemiologic studies concerning work-related allergies in Finland (12).

\section{Skin prick tests}

To assess atopic status, the following common environmental allergens were used: cat, dog, timothy, birch, alder, mugworth, and house dust mite (Dermatophagoides pteronyssinus) (Allergologisk Laboratorium A/S, ALK, Copenhagen, Denmark). Histamine hydrochloride $(10 \mathrm{mg} / \mathrm{ml})$ was used as the positive control. A person with one or more positive reactions to environmental allergens in the skin prick test was defined as atopic. For the employees from plant B, baker's yeast (Saccharomyces cerevisiae, ALK) was also tested.

Commercial enzyme preparations were used as test enzymes. In plant $\mathrm{A}$, the tests included bacterial alphaamylase (BAN $1000 \mathrm{~S}^{\circledR}$, Novo Nordisk A/S, Denmark), fungal alpha-amylase (Sal Conc ${ }^{\oplus}$, Shin Nihhon, Japan), bacterial protease (Neutrase ${ }^{\circledR}$, Novo Nordisk A/S), fungal protease (Veron $\mathrm{AP}^{\circledR}$, Röhm $\mathrm{GmbH}$, Germany), fungal glucose oxidase (Oxygo M 500 ${ }^{\circledR}$, Genencor International, Finland), fungal cellulase (Multifect $\mathrm{CS}^{\circledR}$, Genencor International), and fungal xylanase (Xylanase $250^{\circledR}$, Ueda Chemical Industrial Co, Ltd, Japan). For workers from plant B, glucose oxidase was not used in the tests because it was not handled in that plant. Instead, fungal phytase (Finase $\mathrm{S} 40^{\circledR}$, Alko Ltd, Finland) was added to the test panel, in addition the aforementioned alpha-amylases, proteases, cellulase, and xylanase. The skin prick tests of these workers were performed with 2 cellulases and 2 xylanases, as also another cellulase (Econase CEP Alko Ltd) and xylanase (Ecopulp ${ }^{\circledR}$, Alko Ltd) were tested. The test extracts were prepared, and the tests were performed as described by Vanhanen et al (12). All the tests were performed by the same nurse and read by the same physician. The skin prick tests with these enzyme extracts were negative in a group of 15 unexposed persons.

\section{Immunoglobulin E measurements}

Specific immunoglobulin $E(\operatorname{IgE})$ antibodies to enzymes were measured by a radioallergosorbent test (RAST). Proteins of commercial enzyme preparations were conjugated to paper discs activated by cyanogen bromide by the method of Ceska et al (13). Other reagents were obtained for RAST from Phadebas RAST kits (Pharmacia Diagnostics, Sweden). The results, in kilounits per liter, were based on those of the RAST reference serum (Pharmacia Diagnostics). Values greater than $0.35 \mathrm{kU} / \mathrm{l}$ were defined as positive, indicating sensitization. RAST tests were performed if a person reacted to one or more enzymes in the skin prick test.

\section{Statistical analysis}

In testing the prevalence trend of enzyme sensitization with exposure, the Cochran-Armitage trend test was used (14). For stratified testing and the estimation of the prevalence ratios, methods for determining the relative risk (RR) for prospective studies were used (15). For unstratified $2 \times 2$ table data, the exact method for the rate ratio testing of 2 binomial proportions was used (14). All the statistical P-values are 2 -sided

\section{Results}

Table 2 summarizes the data on atopy, sensitization to enzymes, atopic symptoms, and respiratory symptoms during work in plants $\mathrm{A}$ and $\mathrm{B}$; table 3 presents comparisons of different exposure groups as to enzyme sensitiza-

Table 2. Atopy, enzyme sensitization in nonatopic and atopic employees, atopic symptoms, and respiratory symptoms during work in the three different exposure groups, plants $A$ and $B$ combined.

\begin{tabular}{|c|c|c|c|c|c|c|c|c|c|c|c|c|}
\hline \multirow{3}{*}{$\begin{array}{l}\text { Exposure } \\
\text { group }\end{array}$} & \multicolumn{8}{|c|}{ Skin prick test } & \multirow{2}{*}{\multicolumn{2}{|c|}{$\begin{array}{c}\text { Atopic } \\
\text { symptoms }\end{array}$}} & \multirow{2}{*}{\multicolumn{2}{|c|}{$\begin{array}{l}\text { Respiratory } \\
\text { symptoms } \\
\text { during work }\end{array}$}} \\
\hline & \multicolumn{2}{|c|}{ Atopy } & \multicolumn{2}{|c|}{$\begin{array}{l}\text { Enzyme } \\
\text { positive }\end{array}$} & \multicolumn{2}{|c|}{$\begin{array}{l}\text { Enzyme } \\
\text { positive in } \\
\text { nonatopics }\end{array}$} & \multicolumn{2}{|c|}{$\begin{array}{l}\text { Enzyme } \\
\text { positive in } \\
\text { atopics }\end{array}$} & & & & \\
\hline & $N$ & $\%$ & $N$ & $\%$ & $N$ & $\%$ & $N$ & $\%$ & $N$ & $\%$ & $N$ & $\%$ \\
\hline $\begin{array}{l}\text { 1. Often exposed ( } N=63) \\
\text { 2. Occasionally exposed }(N=51) \\
\text { 3. Rarely or not exposed }(N=59)\end{array}$ & $\begin{array}{r}17 \\
16 \\
8\end{array}$ & $\begin{array}{l}26.9 \\
31.3 \\
13.6\end{array}$ & $\begin{array}{r}13 \\
6 \\
2\end{array}$ & $\begin{array}{r}20.6 \\
11.8 \\
3.4\end{array}$ & $\begin{array}{l}7 \\
2 \\
0\end{array}$ & $\begin{array}{r}15.2 \\
5.7 \\
0\end{array}$ & $\begin{array}{l}6 \\
4 \\
2\end{array}$ & $\begin{array}{l}35.3 \\
25.0 \\
25.0\end{array}$ & $\begin{array}{r}13 \\
9 \\
7\end{array}$ & $\begin{array}{l}20.6 \\
17.6 \\
11.9\end{array}$ & $\begin{array}{r}23 \\
3 \\
1\end{array}$ & $\begin{array}{r}36.5 \\
5.9 \\
1.7\end{array}$ \\
\hline Total $(\mathbb{N}=173)$ & 41 & 23.7 & 21 & 12.1 & 9 & 6.8 & 12 & 29.3 & 29 & 16.8 & 27 & 15.6 \\
\hline
\end{tabular}


Table 3. Comparison of exposure groups by sensitization to enzymes. ( $\mathrm{RR}=$ rate ratio, $95 \% \mathrm{Cl}=95 \%$ confidence interval, group $1=$ often exposed, group 2 = occasionally exposed, group $3=$ rarely or not exposed)

\begin{tabular}{|c|c|c|c|c|c|c|c|c|}
\hline \multirow[t]{2}{*}{$\begin{array}{l}\text { Comparisons by } \\
\text { exposure }\end{array}$} & \multicolumn{2}{|c|}{$\begin{array}{l}\text { Sensitization to } \\
\text { enzymes }\end{array}$} & \multicolumn{2}{|c|}{$\begin{array}{l}\text { Sensitization to } \\
\text { enzymes in nonatopics }\end{array}$} & \multicolumn{2}{|c|}{$\begin{array}{l}\text { Sensitization to } \\
\text { enzymes in atopics }\end{array}$} & \multicolumn{2}{|c|}{$\begin{array}{l}\text { Sensitization to } \\
\text { enzymes, stratified for } \\
\text { atopy }\end{array}$} \\
\hline & $\mathrm{RR}$ & $95 \% \mathrm{Cl}$ & RR & $95 \% \mathrm{Cl}$ & $\mathrm{RR}$ & $95 \% \mathrm{Cl}$ & $\mathrm{RR}$ & $95 \% \mathrm{Cl}$ \\
\hline Group 1 versus group 3 & 5.9 & $1.4-25.3$ & $16.6^{a}$ & $2.44-\infty$ & 1.4 & $0.3-5.5$ & 2.2 & $0.7-7.6$ \\
\hline Groups $1+2$ versus group 3 & 4.9 & $1.2-20.4$ & $12.0^{\mathrm{a}}$ & $1.83-\infty$ & 1.2 & $0.3-4.5$ & 1.8 & $0.5-5.9$ \\
\hline Group 1 versus groups $2+3$ & 2.8 & $1.2-6.4$ & 5.58 & $0.73-340$ & 1.4 & $0.5-3.6$ & 2.2 & $0.9-4.8$ \\
\hline
\end{tabular}

a 0.5 added for each cell.

Table 4. Data on persons sensitized to enzymes in plant $A$. ( $+=$ positive, $-=$ negative)

\begin{tabular}{|c|c|c|c|c|c|c|c|c|c|c|c|}
\hline \multirow{2}{*}{$\begin{array}{l}\text { Case } \\
\text { number }\end{array}$} & \multirow[t]{2}{*}{ Gender } & \multirow[t]{2}{*}{ Smoker } & \multirow{2}{*}{$\begin{array}{l}\text { Duration of } \\
\text { employment } \\
\text { (years) }\end{array}$} & \multirow{2}{*}{$\begin{array}{l}\text { Atopy } \\
\text { in the skin } \\
\text { prick test }\end{array}$} & \multirow[t]{2}{*}{ Occupation } & \multirow{2}{*}{$\begin{array}{l}\text { Exposure } \\
\text { group }\end{array}$} & \multirow{2}{*}{$\begin{array}{l}\text { Symptoms } \\
\text { during work }\end{array}$} & \multicolumn{4}{|c|}{ Skin prick test reactions to enzymes ${ }^{b}$} \\
\hline & & & & & & & & Cellulase & Xylanase & $\begin{array}{c}\alpha \text {-Amyl- } \\
\text { ase } \\
\text { (bacterial) }\end{array}$ & $\begin{array}{c}\alpha \text {-Amyl- } \\
\text { ase } \\
\text { (fungal) }\end{array}$ \\
\hline 1. & Male & No & 3 & + & Researcher & 2 & None & + & + & - & + \\
\hline 2. & Male & No & 3 & + & Researcher & 2 & None & + & + & - & - \\
\hline 3. & Female & No & 3 & + & Secretary & 3 & None & + & + & - & + \\
\hline 4. & Female & No & 4 & + & Laboratory assistant & t 1 & $\begin{array}{l}\text { Rhinorrhea, } \\
\text { cough }\end{array}$ & + & + & + & - \\
\hline 5. & Female & No & 3 & - & Laboratory assistant & $t 2$ & $\begin{array}{l}\text { Rhinorrhea, } \\
\text { cough }\end{array}$ & + & + & - & - \\
\hline 6. & Male & Yes & 12 & + & Laboratory assistant & t 2 & None & + & + & - & - \\
\hline 7. & Female & No & 2 & - & Laboratory assistant & $t \quad 2$ & None & + & + & - & - \\
\hline 8. & Female & Yes & 3 & + & Laboratory assistant & t 1 & $\begin{array}{l}\text { Rhinorrhea, } \\
\text { cough }\end{array}$ & - & + & - & - \\
\hline 9. & Male & No & 5 & + & Researcher & 1 & None & - & - & + & - \\
\hline 10. & Male & Yes & 11 & - & $\begin{array}{l}\text { Project } \\
\text { manager }\end{array}$ & 1 & None & - & - & - & + \\
\hline 11. & Male & No & 20 & + & Researcher & 1 & None & - & - & - & + \\
\hline
\end{tabular}

a Exposure groups: 1 = often exposed; 2 = occasionally exposed; 3 = rarely or not exposed.

- All were negative to glucose oxidase and bacterial and fungal protease.

tion, and tables 4 and 5 offer summaries of the detailed data of the sensitized employees.

\section{Skin prick tests and specific immunoglobulin $E$ measurements}

According to the skin prick tests, $27.8 \%$ of the tested employees in plant $\mathrm{A}$ and $24 \%$ in plant $\mathrm{B}$ were atopic. Eleven (12\%) persons in plant A and $10(13 \%)$ in plant B were sensitized to enzymes. Enzyme-specific IgE was detected in 7 persons positive in the skin prick test from plant A and, respectively, in 7 from plant B. After 6 months the enzyme skin prick tests and RAST tests were repeated for the 11 persons from laboratory A who were enzyme positive; the results were identical, except for 1 person (number 11 in table 4). His earlier positive prick test to fungal alpha-amylase was then negative. In plant B, follow-up tests were performed for 56 employees 1 year after the first study. No new cases of enzyme sensitization were found. Nine of the 10 enzyme positive persons were still positive.

\section{Association between exposure, sensitization and symptoms at work}

The prevalence of enzyme sensitization increased with increasing exposure (table 2). The exposure-response linear trend (table 3) was statistically significant $(\mathrm{P}=0.003)$, although it weakened, but remained statistically significant, after stratification for atopy $(\mathrm{P}=0.01)$. Atopy was associated with enzyme sensitization [RR $4.3,95 \%$ confidence interval $(95 \%$ CI) $2.04-9.04$, $\mathrm{P}=0.001]$. Smoking was not associated with enzyme sensitization, as shown by a comparison of the current and ex-smokers with the nonsmokers (RR 1.3, 95\% CI $0.55-2.84)$.

Respiratory symptoms (rhinitis, cough, dyspnea) at work were reported by 27 people $(15.6 \%)$. Rhinitis (rhinorrhea or stuffy nose or both) was the most common symptom. The prevalence of symptoms increased as the exposure increased (table 2). The calculated exposureresponse linear trend was statistically significant $(\mathrm{P}=0.001)$ and remained so after stratification for atopy. 
Table 5. Data on persons sensitized in plant B. (+ = positive, $-=$ negative)

\begin{tabular}{|c|c|c|c|c|c|c|c|c|c|c|c|}
\hline \multirow{2}{*}{$\begin{array}{l}\text { Case } \\
\text { number }\end{array}$} & \multirow[t]{2}{*}{ Gender } & \multirow[t]{2}{*}{ Smoker } & \multirow{2}{*}{$\begin{array}{l}\text { Duration of } \\
\text { employment } \\
\text { (years) }\end{array}$} & \multirow{2}{*}{$\begin{array}{c}\text { Atopy } \\
\text { in the skin } \\
\text { prick test }\end{array}$} & \multirow[t]{2}{*}{ Occupation } & \multirow{2}{*}{$\begin{array}{l}\text { Exposure } \\
\text { group }\end{array}$} & \multirow{2}{*}{$\begin{array}{l}\text { Symptoms } \\
\text { during work }\end{array}$} & \multicolumn{4}{|c|}{ Skin prick test reactions to enzymes ${ }^{b}$} \\
\hline & & & & & & & & Cellulase & Xylanase & Phytase & $\begin{array}{c}\alpha \text {-Amyl- } \\
\text { ase } \\
\text { (fungal) }\end{array}$ \\
\hline 1. & Female & No & 4 & + & Secretary & 2 & $\begin{array}{l}\text { Rhinorrhea, } \\
\text { cough }\end{array}$ & + & + & - & - \\
\hline 2. & Female & Yes & 8 & - & $\begin{array}{l}\text { Laboratory } \\
\text { assistant }\end{array}$ & 1 & Rhinorrhea & + & + & - & - \\
\hline 3. & Male & No & 40 & - & $\begin{array}{l}\text { Process man } \\
\text { (yeast production) }\end{array}$ & 3 & None & + & + & - & - \\
\hline 4. & Fernale & Yes & 8 & - & $\begin{array}{l}\text { Laboratory } \\
\text { assistant }\end{array}$ & 1 & $\begin{array}{l}\text { Eye } \\
\text { irritation }\end{array}$ & + & + & - & - \\
\hline 5. & Male & Yes & 5 & + & Process man & 1 & $\begin{array}{l}\text { Rhinorrhea, } \\
\text { dyspnea }\end{array}$ & + & + & - & - \\
\hline 6. & Female & No & 2 & - & $\begin{array}{l}\text { Laboratory } \\
\text { assistant }\end{array}$ & 1 & Rhinorrhea & + & + & - & - \\
\hline 7. & Female & Yes & 7 & + & $\begin{array}{l}\text { Laboratory } \\
\text { assistant }\end{array}$ & 1 & $\begin{array}{l}\text { Rhinorrhea, } \\
\text { eye irritation }\end{array}$ & + & + & + & + \\
\hline 8. & Female & No & 3 & - & $\begin{array}{l}\text { Cleaning } \\
\text { woman }\end{array}$ & 1 & Rhinorrhea & - & - & + & - \\
\hline 9. & Female & No & 3 & - & $\begin{array}{l}\text { Cleaning } \\
\text { woman }\end{array}$ & 1 & $\begin{array}{l}\text { Rhinorrhea, } \\
\text { cough }\end{array}$ & - & - & + & - \\
\hline 10. & Female & No & 2 & - & Researcher & 1 & $\begin{array}{l}\text { Rhinorrhea, } \\
\text { cough, urticaria }\end{array}$ & - & - & + & - \\
\hline
\end{tabular}

a Exposure groups: 1 = often exposed; 2 = occasionally exposed; 3 = rarely or not exposed.

b All were negative to bacterial $\alpha$-amylase and bacterial and fungal protease.

The symptoms were associated with sensitization to enzymes (RR 5.7, 95\% CI 2.4-14.8).

\section{Discussion}

We investigated enzyme sensitization in 2 plants producing industrial enzymes. The plants were doing research in the fast growing field of biotechnology, and they were developing new enzymes and applications. The risk of allergy was not fully recognized. This was probably due to the fact that amylases and cellulases have been regarded as safer than proteases. Cases of occupational asthma appeared in both plants however, and they caused the initiation of this cross-sectional study.

The prevalence of sensitization to enzymes was comparatively high, $12-13 \%$. Prevalences of $5 \%$ to $40 \%$ (in heavily exposed groups) were reported in the detergent industry in the early 1970s (2), and recent studies have found rates of $5-8 \%$ in bakeries $(6,7,12)$. Enzyme sensitization was the most common towards cellulase and xylanase, being the main products of the plants. Simultaneous reactions to cellulase and xylanase extracts were common. The enzymes are produced by the same microorganism, and, apart from the main enzyme protein, they contain one or more minor enzyme activities. Sensitization to both bacterial and fungal alpha-amylases, separately, were also found; this result suggests individual antigenic characteristics. Phytase sensitization was noted, which, to our knowledge, has not been re- ported before. Phytase is a new enzyme component in animal feed.

The skin prick test results did not totally coincide with in vitro measurements of enzyme-specific $\operatorname{IgE}$ (RAST), which is a common finding (7). IgG antibodies to enzymes were not determined in our study. The pathogenetic significance of precipitating antibodies has remained unclear in previous studies, as no association has been found between them and symptoms $(9,16)$. Allergic alveolitis due to enzymes seems to be rare (4).

Sensitization to enzymes was distinctly more prevalent among the atopic than the nonatopic persons; this finding is in accordance with earlier results $(2,4,6,7)$. Interestingly, a clear exposure-response relationship was demonstrated for both enzyme sensitization and respiratory symptoms during work; the association was distinct for the entire study population and for nonatopics. An exposure-response relationship for atopics could not be demonstrated owing to the small number of atopics $(\mathrm{N}=8)$ in the low-exposure group, where, moreover, 2 persons were sensitized. A recent Dutch study on alphaamylase sensitization among bakers found similarly a positive association between amylase allergen exposure and positivity to the enzyme in skin prick tests (7). The association was demonstrated only for atopic persons, however, not for nonatopics. The authors suggested that the exposure levels for those not in the high-exposure group were not high enough to sensitize nonatopics but were high enough for atopics. In our study, it is likely 
that groups 2 and 3 were not clearly distinguished from each other by exposure, and misclassification could have occurred that left the risk of sensitization of atopics by and large equally great in these groups. The exposure criteria for group 1 were more clear-cut and, according to the results, appear to distinguish between the mostexposed workers and the less-exposed ones.

Unfortunately, systematic data on enzyme concentrations in air could not be obtained at the time of the study. However, some occasional measurements indicate the exposure levels which prevailed in the laboratories. A cellulase, cellobiohydrolase I (CBH I), had been measured by the companies for the evaluation of technical improvements with an immunologic method (12). Air concentrations CBH I of $40-60 \mathrm{ng} / \mathrm{m}^{3}$ were detected during the weighing of samples in a laminar flow cabin and in a weighing room. There are no data from work phases in which higher exposure to enzymes was likely earlier, such as the mixing, drying, and packing of enzymes. In comparison, measurements in another plant, where the spray-drying (as in plant B) and packing of cellulase were performed on a subcontract basis, revealed CBH I air concentrations of $6-7 \mu \mathrm{g} / \mathrm{m}^{3}$ during packing. The highest concentrations, up to $120 \mu \mathrm{g} / \mathrm{m}^{3}$, were measured in a spray-drying hall due to obvious leaks in the conveyor lines.

Some separate cases emphasize the allergenic potential of enzymes and the need for isolating enzyme-handling areas whenever possible. For example, in both plants one secretary was sensitized to enzymes. One person did not handle enzymes at all, but was exposed when visiting enzyme-handling areas or when employees, sometimes in dusty clothes, visited her room. Another person was exposed to enzymes when mailing and opening packages containing small enzyme samples. One employee, working in yeast production in a separate building, was apparently exposed on occasional visits to the enzyme production areas.

From the point of view of preventing sensitization, some of the results are important. First, the prevalence of sensitization and work-related hypersensitivity symptoms clearly emphasize the need for preventive measures. Second, atopics are clearly more susceptible to sensitization than nonatopics, the difference being the most conspicuous at low exposure levels. In addition the occasional and obviously minute degree of exposure leading to sensitization of some cases is noteworthy. Third, nonatopics also become sensitized and display an exposure-response relationship. It follows that prevention should focus on controlling exposure. Means of dust control were introduced already in the $1960 \mathrm{~s}(1,2)$. They include the use of less dusty products, for example, granules and liquid enzymes, enclosure and segregation of processes, local exhaust hoods, and the use of respiratory protective devices.
The former recommendation of excluding atopic persons at recruitment in some industries (2) would likely reduce the number of cases of sensitization. However, it would not abolish the problem, as some nonatopics become sensitized anyway and develop hypersensitivities. Owing to the low predictive value of atopy, the exclusion of atopics is an expensive solution that has been discouraged; in addition the majority of atopics will eventually not contract any disease $(17,18)$. Finally, this practice tends to draw the attention from the real cause of sensitization, the exposure levels at work. Although the no-effect level for enzymes is unknown, the demonstration of an exposure-response relationship shows that it will always be worthwhile to lower exposure levels to protect the vast majority of workers from sensitization. It was unfortunately not practicable to measure systematically the air concentrations of enzymes, and the few measurements available only reflect the concentration levels in certain worktasks. The setting of occupational exposure limits for enzymes will require systematic measurements of enzyme concentrations in the workair, along with the testing of employees.

\section{Acknowledgments}

We acknowledge the help of Ms Riitta Valio and Ms Terttu Mäkelä in the allergy testing. We are also grateful to Mr Heikki Hokkanen for providing information on the exposure conditions and to Ms Ulla Tiikkainen for her comments on the manuscript. We also wish to particularly thank the employees who participated in the study, as well as the management and occupational health care units of the plants.

The work was supported by grants from the Finnish Work Environment Fund.

\section{References}

1. Flindt MLH. Pulmonary disease due to inhalation of derivatives of bacillus subtilis containing proteolytic enzymes. Lancet 1969;1:1177-81.

2. Gilson TL, Juniper CP, Martin RB, Weill H. Biological effects of proteolytic enzymes. Thorax 1976;31:621-34.

3. Gerhartz W, ed. Enzymes in industry. Weinheim (Germany): VCH Verlagsgesellschaft, 1990.

4. Brisman J. Industrial enzymes: the Nordic expert group for criteria documentation of health risks from chemicals. Solna (Sweden): Arbetsmiljöinstitutet, 1994. Arbete och Hälsa 28.

5. Baur X, Fruhmann G, Haug B, Rasche B, Reiher W, Weiss W. Role of Aspergillus amylase in bakers' asthma. Lancet 1986; $1: 43$.

6. Cullinan P, Lowson D, Nieuwenhuijsen MJ, Sandiford C, Tee $\mathrm{RD}$, Venables KM, et al. Work related symptoms, sensitization, and estimated exposure in workers not previously ex- 
posed to flour. Occup Environ Med 1994;51:579—83.

7. Houba R, Heederik DJJ, Doekes G, van Run PEM. Exposuresensitization relationship for $\alpha$-amylase allergens in the baking industry. Am J Respir Crit Care Med 1996;154:130 - 6.

8. Ransom JH, Schuster M. Allergic reaction to enzymes used in plant cloning experiments. J Allergy Clin Immunol 1981;67:5: $412-5$.

9. Losada E, Hijonosa M, Quirce S, Sanchez-Cano M, Moneo I. Occupational asthma caused by alpha-amylase inhalation: clinical and immunological findings and bronchial response patterns. J Allergy Clin Immunol 1992;89:118—25.

10. Harkki A, Mäntylä A, Penttilä M, Muttilainen S, Buhler R, Suominen $\mathrm{P}$, et al. Genetic engineering of Trichoderma to produce strains with novel cellulase profiles. Enzyme Microb Technol 1991;13:227-33.

11. Tarvainen K, Kanerva L, Tupasela $\mathrm{O}$, Grenguist-Nordén B, Jolanki R, Estlander T, et al. Allergy from cellulase and xylanase enzymes. Clin Exp Allergy 1991;21:609-15.

12. Vanhanen M, Tuomi T, Hokkanen H, Tupasela O, Tuomainen A, Holmberg PC, et al. Enzyme exposure and enzyme sensiti- zation in the baking industry. Occup Environ Med 1996;53: $670-6$.

13. Ceska M, Eriksson R, Varga JM. Radioimmunosorbent assay of allergens. J Allergy Clin Immunol 1972;49:1_-9.

14. Cytel Software Corporation. StatXact 3 for Windows: statistical software for exact nonparametric inference, user manual. Cambridge: Cytel Software Corporation, 1995.

15. SAS Institute Inc. SAS procedures guide, version 6.3 rd edition. Cary (NC): SAS Institute Inc, 1990

16. Brisman J, Belin L. Clinical and immunological responses to occupational exposure to $\alpha$-amylase in the baking industry. $\mathrm{Br}$ J Ind Med 1991:48:604-8.

17. Pepys J. Allergic asthma to Bacillus subtilis enzyme: a model for the effects of inhalable proteins. Am J Ind Med 1992;21: $587-93$.

18. Nordman H. Occupational asthma - time for prevention. Scand J Work Environ Health 1994;20(special issue):10815.

Received for publication: 25 February 1997 